九州大学学術情報リポジトリ

Kyushu University Institutional Repository

\title{
A Preliminary Conceptual Design Approach of Food Waste Composter Design
}

Angie, $\mathrm{Ng}$

Faculty of Electrical Engineering, Universiti Teknikal Malaysia Melaka

Ernie Mat Tokit

Faculty of Electrical Engineering, Universiti Teknikal Malaysia Melaka

Norasra Abd Rahman

Fakulti Kejuruteraan Mekanikal, Universiti Teknikal Malaysia Melaka

Fatimah Al Zahrah Mohamad Saat

Fakulti Kejuruteraan Mekanikal, Universiti Teknikal Malaysia Melaka

他

https://doi.org/10.5109/4480721

出版情報 : Evergreen. 8 (2)，pp.397-407，2021-06. 九州大学グリーンテクノロジー研究教育センター バージョン：

権利関係 : 


\title{
A Preliminary Conceptual Design Approach of Food Waste Composter Design
}

\author{
Ng Angie ${ }^{1}$, Ernie Mat Tokit ${ }^{1,2, *}$, Norasra Abd Rahman ${ }^{1,2}$, Fatimah Al Zahrah \\ Mohamad Saat ${ }^{1,2,3}$, Fadhilah Shikh Anuar ${ }^{3,4}$, Nona Merry M. Mitan ${ }^{5}$, \\ ${ }^{1}$ Fakulti Kejuruteraan Mekanikal, Universiti Teknikal Malaysia Melaka, \\ Hang Tuah Jaya, 76100 Durian Tunggal, Melaka, Malaysia \\ ${ }^{2}$ Centre for Advanced Research on Energy, Universiti Teknikal Malaysia Melaka, \\ ${ }^{3}$ Green Design \& Manufacturing Research Group, Centre of Excellence Geopolymer \& Green Technology, \\ Universiti Malaysia Perlis, Malaysia, Sg. Chuchuh, Arau, Jalan Wang Ulu, 01000 Kangar, Perlis \\ ${ }^{4}$ Fakulti Teknologi Kejuruteraan Mekanikal dan Pembuatan, Universiti Teknikal Malaysia Melaka, \\ Hang Tuah Jaya, Durian Tunggal, 76100 Melaka, Malaysia \\ ${ }^{5}$ Department of Chemistry, Faculty of Science and Computer, Universitas Pertamina, 12220 Kebayoran Lama, \\ Jakarta, Indonesia
}

*Corresponding E-mail: ernie@utem.edu.my

(Received January 7, 2021; Revised April 26, 2021; accepted April 26, 2021).

\begin{abstract}
This paper reports the conceptual design of a household kitchen food waste composter. Several conceptual approaches, such as Quality Function Deployment (QFD), Concept Generation, and Concept of Evaluation using PUGH Method are implemented. The component selection is applied using House of Quality method, and the final design is presented and selected using PUGH Method. Design 1 is selected as the best composter design. The material selection and the cost of the components are also presented. The conceptual design approach highlights its benefit as the preliminary method in designing the food waste composter.
\end{abstract}

Keywords: conceptual design approach, food waste composter, food waste

\section{Introduction}

Malaysia has undergone a drastic increase in the growth of Municipal Solid Waste (MSW). The generation of 1.17 kilogram per capita per day in 2018 had almost doubled over the previous thirteen years ${ }^{1}$. By excluding the generation of MSW from construction and manufacturing activities, food waste made up about $44.5 \%$ of the overall household MSW generated, which was the largest proportion, followed by plastic waste and diapers. However, more than half of the waste generated was sent to landfills, while about $40 \%$ of them could have been recycled ${ }^{1)}$.

According to the Food Recovery Hierarchy from the United States Environmental Protection Agency (EPA), composting is a preferable method of handling food waste to produce a nutrient-rich soil conditioner than direct disposal to landfill or even incineration. This is because harmful by-products are potentially produced through landfills ${ }^{2)}$ and incineration, such as the emission of greenhouse gases in a great amount; hence, causing ozone thinning. Apart from that, some researchers ${ }^{3)}$ applied bioconversion as a method for designing composting plants. In Malaysia, there is no efficient management or separation of food waste from the other categories of MSW, with the reliance solely on landfills or incineration for disposal as other waste. Thus, Malaysia needs other initiatives to manage food waste more effectively in an environmentally-friendly manner ${ }^{4}$.

There are two common types of composting methods used in food waste composting, which are aerobic composting and anaerobic digestion. The key difference between these two methods is the presence of oxygen in aerobic composting to start the composting process, whereas anaerobic digestion begins the process with the absence or limited supply of oxygen. Aerobic microorganisms decompose organic waste to produce compost criteria at near maturity ${ }^{5)}$ and by-products such as water, ammonia, heat, and carbon dioxide. Meanwhile, for anaerobic digestion, anaerobic microorganisms break down the waste and produce intermediate substances like carbon dioxide, hydrogen sulphide, methane, and a potentially foul odour. However, in general, aerobic composting works at a higher rate of composting compared to anaerobic digestion, with both methods of composting being conducted under respective optimal conditions like temperature, $\mathrm{pH}$, carbon to nitrogen ratio, 
and moisture content ${ }^{6)}$.

To encourage the composting of food waste, marketable food waste composters have already been introduced in the market such as Zera Food Recycler ${ }^{7}$ and Food Cycler FC- $30^{8}$ ). A composter is designed to be installed in every house to inculcate awareness on zero solid waste for a greener earth.

Primarily, most household waste composters are designed in a rectangular shape to provide convenience for the end-user since they would take less space in the kitchen. The conceptual design approach highlights the significance of illustrating factors that might not be considered by humans while fulfilling some requirements set up by the end-users. This concept tailors the product design to the required needs in wide industrial areas, such as transport design ${ }^{9)}$, energy generation ${ }^{10)}$, and desalination process $^{11)}$; some researchers have investigated the integration of TRIZ (Theory of Inventive Problem Solving) method into this design concept ${ }^{12)}$.

The initial step in this conceptual design approach is by conducting a survey, where the customer needs are highlighted to meet requirements ${ }^{13)}$. This survey is significant to provide a high-quality product that satisfies the customer. The functional structure of the products is then developed and applied in the reintegrated products ${ }^{14)}$ and also in the development of a sticker removal machine 15), which divides the main function into smaller department functions. The functional structure details the process between the input and output of a product ${ }^{16)}$. Based on the morphological chart ${ }^{16)}$, which relates to the combination of various functions ${ }^{17)}$, the divergence of products is designed. The final product utilisation of the decision-matrix method (PUGH method) is applied to select the best product design, as generated in the selection of the plant layout ${ }^{18)}$. Besides, the same method is compared with KANO-MODEL Technique and the work of both methods is concluded to be helpful as a tool for market survey analysis ${ }^{19}$.

Therefore, this study illustrates the conceptual design approach in designing alternative composter design by describing the clarity of components in detail and by selecting the final product out of several designs to be shown later.

\section{Methodology}

The earliest design process involved the basic calculation of the food waste volume capacity, the heating capacity, and the power needed from the auxiliary components. The theoretical calculation concept had been applied in other design processes, such as in calculating the thermodynamic process to design a geothermal power plant $^{20)}$ and solar AC system ${ }^{21)}$, with the combination of simulation through designing a micropump ${ }^{22)}$, and designing a wind turbine for low Reynolds number ${ }^{23}$.

This conceptual design applied the Morphological Chart to select the auxiliary component involved in the composter. Meanwhile, the House of Quality corresponds to the composter design that matches the end-user's needs.

To design the composter, the volume capacity of the composter is designed for six persons per household. The composting chamber with an automated mixing system to mix the compost in intervals during the composting process are usually designed with rotating mixing mechanisms, such as a mixing shaft and blades or a rotating composting chamber. As such, the cylindrical design of a composting chamber ensures even mixing of the whole compost material. Thus, the volume of the composting chamber is shown in Eq. 1.

$$
V=\pi x r^{2} x h
$$

The composter is equipped with an electrically controlled motor to allow the automation of the mechanism in providing auto-stirring of the compost material. The motor horsepower is significant in ensuring the generation of sufficient torque throughout the process. According to Chiplunkar et al. ${ }^{24)}$ the steps for selecting a suitable horsepower are shown in Eq. 2 to 5.

$$
\text { Torque, } \quad \tau=F \times r
$$

The motor horsepower is calculated using Eq. 3.

$$
\text { Power, } \quad P=T \times \omega
$$

The installation of a heating system on the food waste composter is unnecessary, but it can be found in most food waste composters marketed in countries with a climate temperature lower than the desirable composting temperature, which is approximately 55 to $60^{\circ} \mathrm{C}$. Among the countries involved are Qatar, India, and the United States, with a temperature range from -3 to $45{ }^{\circ} \mathrm{C}$. Benjawan et al. ${ }^{25)}$ claimed that the ambient temperature of the food waste composter did not have a direct relationship with the rate and the quality of the compost. Besides, the heating mechanism was vital in providing a stable and optimal temperature, which maximised the rate of composting while producing a higher quality of the compost outcome.

The power consumption of the heating coil is equal to its heat generation per hour to maintain the desired temperature in the composting chamber throughout the composting process. Chiplunkar et al. ${ }^{24)}$ designed a kitchen waste composter with a capacity of 10 to $15 \mathrm{~kg}$. The power consumption of the heating coil is calculated by adopting the heat generation formula, as shown in Eq. 4.

$$
Q=m c\left(T_{2}-T_{1}\right)
$$

The initial temperature of the heating coil is taken at room temperature, $25{ }^{\circ} \mathrm{C}(298 \mathrm{~K})$, and the final temperature of the heating coil is taken at the optimal composting temperature, $60^{\circ} \mathrm{C}$. The density of the Nickel-Chromium heating coil is $1.225 \mathrm{~kg} / \mathrm{m}^{3}$, whereas the mass of the heating coil (Nickel-Chromium) is illustrated by Eq. 5 .

$$
m=\rho V
$$

The power consumption of the heating coil is defined as the heat generation per hour in an equilibrium system. This applies the conservation of energy at which the 
energy input is equal to the energy output. The energy input refers to the power consumption, while the energy output is the heat generated by the heating coil that causes an increase in the interior temperature of the composting chamber. Therefore, the power consumption of the Nickel-Chromium heating coil is calculated using Eq. 6.

$$
P=Q / T
$$

The yield strength of the kitchen food waste is important to determine the motor horsepower and the specifications of gear to be used for the shredding mechanism. A bovine trabecular bone is selected as the hardest food waste that can be found in a common household kitchen. According to Kaplan, S. J. et al. ${ }^{26)}$ the yield strength of a bovine trabecular bone in compression was $12.4 \pm 3.2 \mathrm{MPa}$. Therefore, the maximum yield strength value of $15.6 \mathrm{MPa}$ is used for the design so that a higher torque can be produced by the shredder motor. The shredder is used to shred most of the kitchen food waste into smaller particles for higher efficiency of the composting process. The minimum required force for the shredding process can be calculated by taking into account the maximum yield strength of kitchen food waste as shown in Eq. 7.

$$
\sigma=F_{\min } / A
$$

Moreover, the stress is equal to the yield strength of the kitchen food waste. The minimum force is determined as the minimum force required to overcome the yield strength of the kitchen food waste. Therefore, the force is calculated as the product of yield strength of the kitchen food waste and the cross-sectional area of the shredder blades.

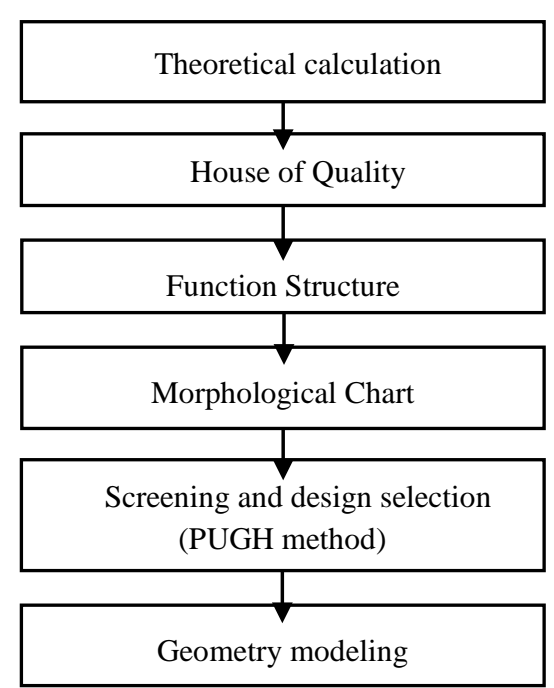

Fig.1: Flowchart of the conceptual design process

By taking into account the assumption on the maximum yield strength of the kitchen food waste and the minimum force required to overcome its yield strength, the horsepower and the power consumption of the shredding motor are calculated using Eq. 2 and 3. The preliminary design process is summarised as in the flowchart shown in Fig. 1.

\section{Results and discussion}

This section explains the steps used in the conceptual design of the food waste composter. The later structural analysis will be done to further investigate the strength of the composter.

\subsection{Design Elements}

The composter design elements have been identified based on the customer requirement and summarised in Fig. 2. The main components of the composter are the control panel, the mixing mechanism of the waste, the ventilation system, the heating mechanism used to heat the waste, and the main body of the composter bin to store the waste. The safety features and the additional auxiliary parts are also included in this figure. This figure transforms the design elements into more specific customer requirements.

\subsection{House of Quality, HOQ}

The customer requirements and engineering characteristics are tabulated accordingly to form a House of Quality (HOQ). According to the rank score ${ }^{27)}$ as shown in Fig. 2, the heating coil with a sensor is rated as the most important engineering characteristics, with a raw score of 146 comprising $14.3 \%$ of the relative weight. This indicates that the product development should be prioritised to fulfil the engineering characteristics based on the rank order. For this project, the sequence of rank order for the engineering characteristics is the heating coil with a sensor, material toughness, shredder, corrosion resistance, mixing blade, ventilation, power consumption, the product volume, timer, and lock sensor. The lock sensor is classified as the lowest rank order because it comprises the least relative weight of the total score, with a value of $4.4 \%$.

Five selected competitors served as the benchmark for the evaluation based on the customer requirements in this project. The five competitors include the compost bin for Indian kitchen ${ }^{28)}$, a small-scale kitchen waste composting machine $^{29)}$, a kitchen waste composting machine ${ }^{25)}$, Thai household composter ${ }^{23)}$ and an organic fertiliser ${ }^{30)}$ from composting food waste; all are assessed from their level of satisfaction to fulfil the respective customer requirements. Based on the evaluation parameters in this HOQ, the small-scale kitchen waste composting machine is ranked as the highest among the other competitors, with a raw score of 107 . This indicates that it has a higher connection with the customer requirements in this project and it should be prioritised in the sequence when the benchmarking is performed for reverse engineering on the related working mechanisms.

\subsection{Function Structure}

The operational process of the kitchen food waste composter is analysed and broken down to form general and detailed function structures to indicate inputs and 
outputs, as well as the sub-processes involved in the composting of food waste. A general function structure is generated, as shown in Fig. 4. After these series of subprocesses, the major process of converting the kitchen food waste into compost is achieved by producing output which includes composted material and switching off the LED indicator.

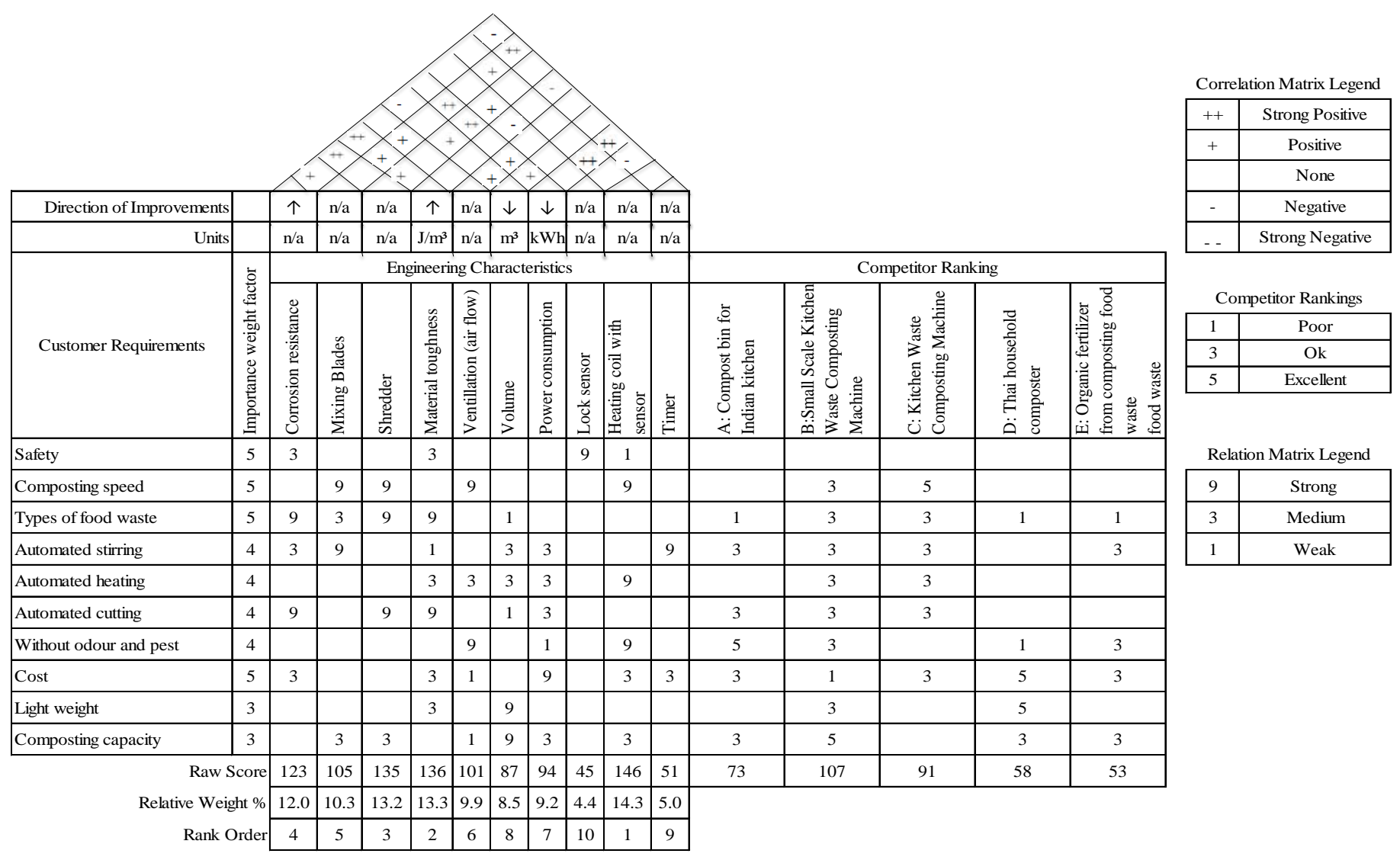

Fig. 2: House of Quality ${ }^{27)}$

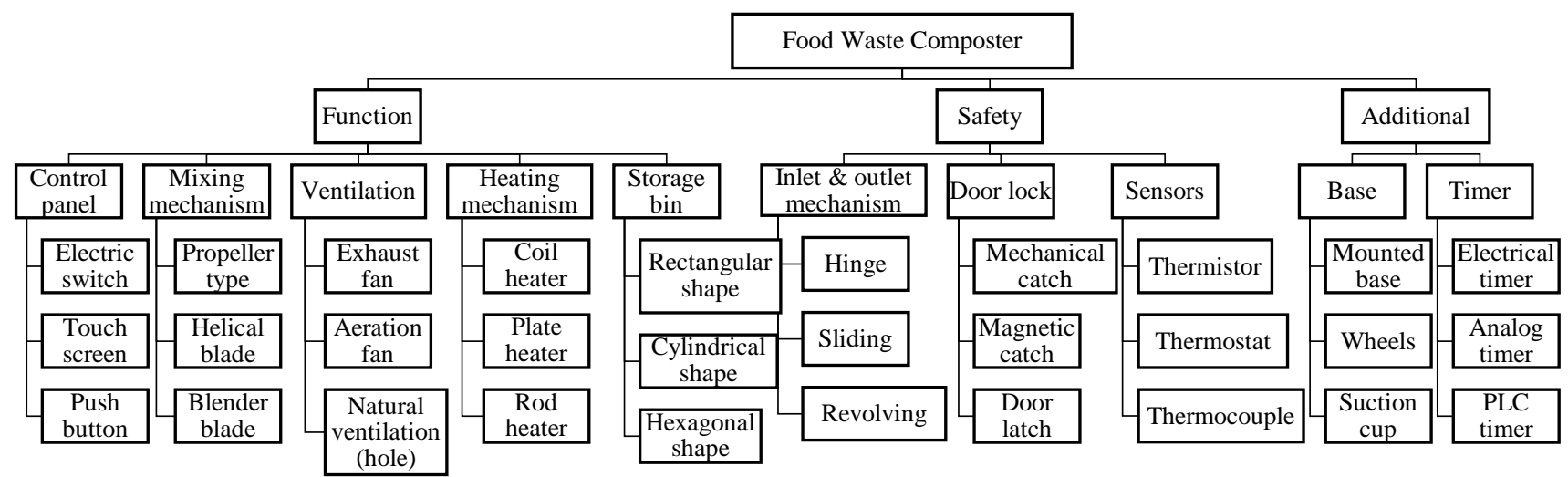

Fig. 3: Product specifications 


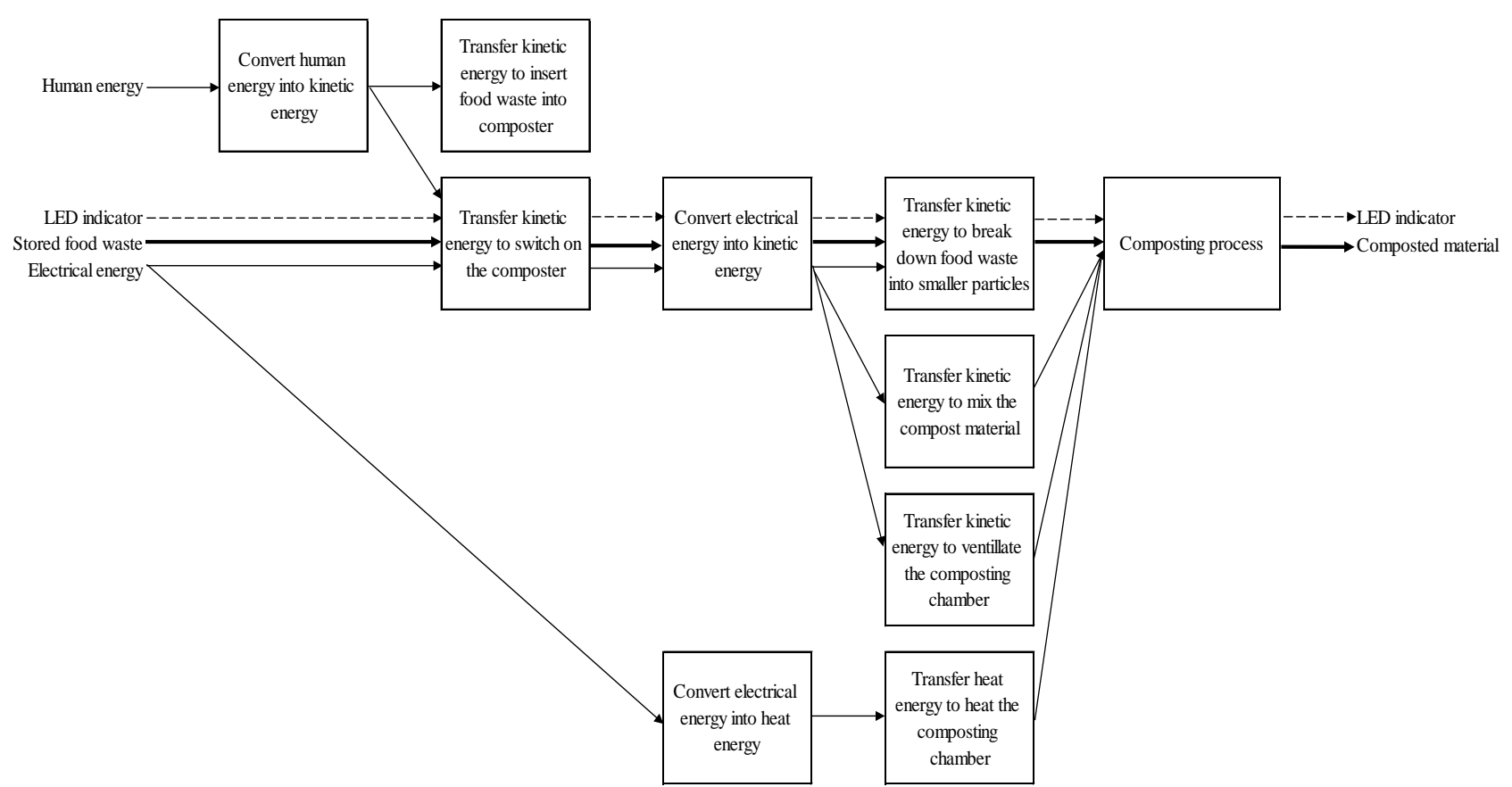

Fig. 4: Composter function structure

\subsection{Morphological Chart}

The morphological chart shows the design concept of each component that is used in the conceptual designing of the kitchen food waste composter. Several options of the components have been highlighted here as the basis of the composter. Three options have been used for each component function. This includes the control panel, inlet and outlet mechanism, safety features, mixing mechanism, ventilation mechanism, temperature sensor, timer, composting chamber, heating mechanism, heating element, and the base of the machine. The detail of each function is shown in Table 1.

Table 1. Morphological chart for some of the components used for the kitchen food waste composter ${ }^{31)}$

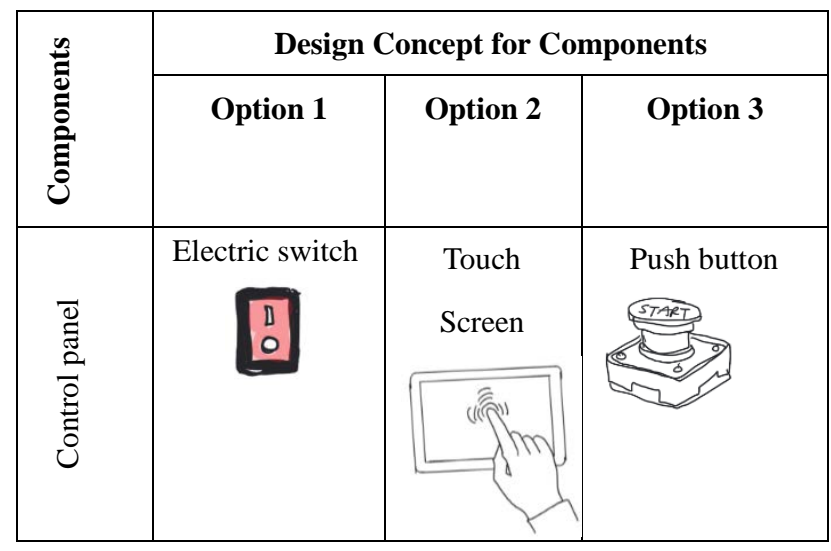

\begin{tabular}{|c|c|c|c|}
\hline 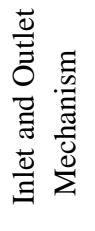 & Hinge & Sliding & Revolving \\
\hline 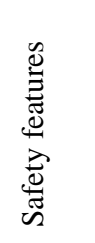 & $\begin{array}{l}\text { Mechanical } \\
\text { catch }\end{array}$ & $\begin{array}{l}\text { Magnetic } \\
\text { catch }\end{array}$ & $\begin{array}{l}\text { Safety Door } \\
\text { Lock }\end{array}$ \\
\hline 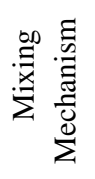 & Propeller & Helical blade & Blender blade \\
\hline 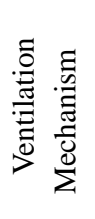 & Exhaust fan & Aeration fan & $\begin{array}{r}\text { Natural } \\
\text { ventilation } \\
\text { (Hole) }\end{array}$ \\
\hline 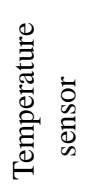 & Thermistor & Thermostat & Thermocouple \\
\hline
\end{tabular}

\subsection{Conceptual Design}

The design concepts for components from each of the sub-problems as discussed in the morphological chart are 
combined to form different designs of a complete solution, which serve as a draft of design ideas before selecting the final concept and proceeding with the technical drawing. The possible combinations of the designs are illustrated in Fig. 5(a) - (d), respectively.

In Design 1, the major mixing component includes a straight bevel gear assembly that transfers torque from the motor to produce a rotational force onto the helical blade to start the mixing process. For the shredding mechanism, the same motor is used by connecting it with a pulley system to transfer the torque onto the two complementary shafts, with blades arranged in a position to shred the food waste inserted into the chamber. Composted material is withdrawn from the composting chamber through a welded sliding passage into the collection bin to be removed from the kitchen food waste composter.

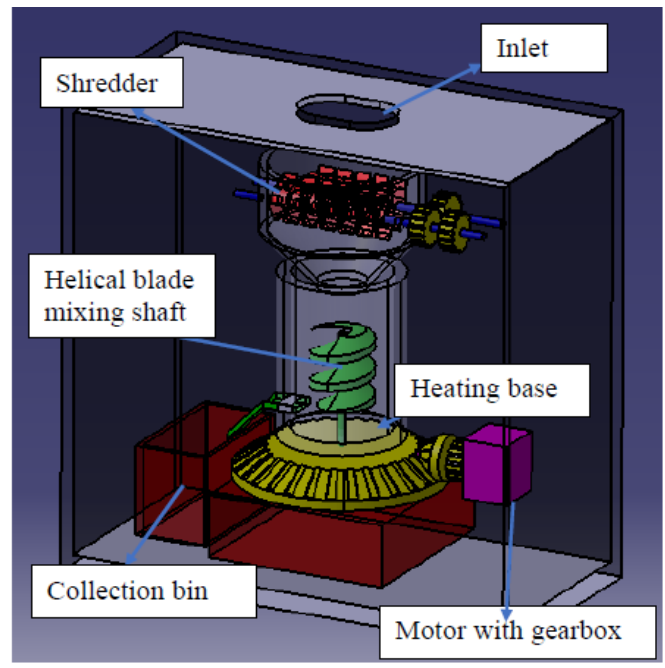

(a)

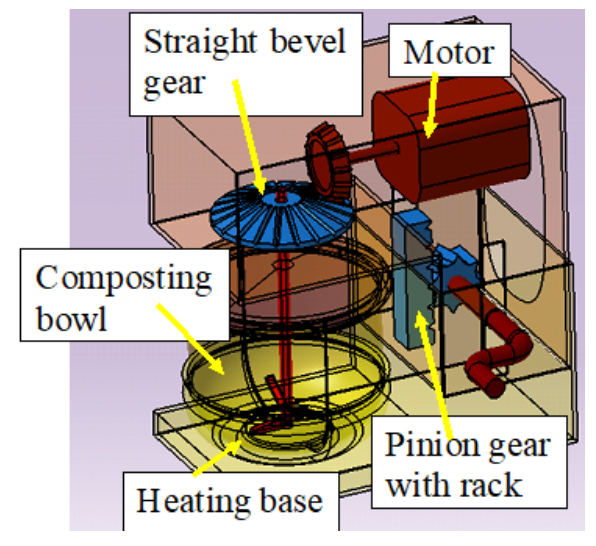

(b)

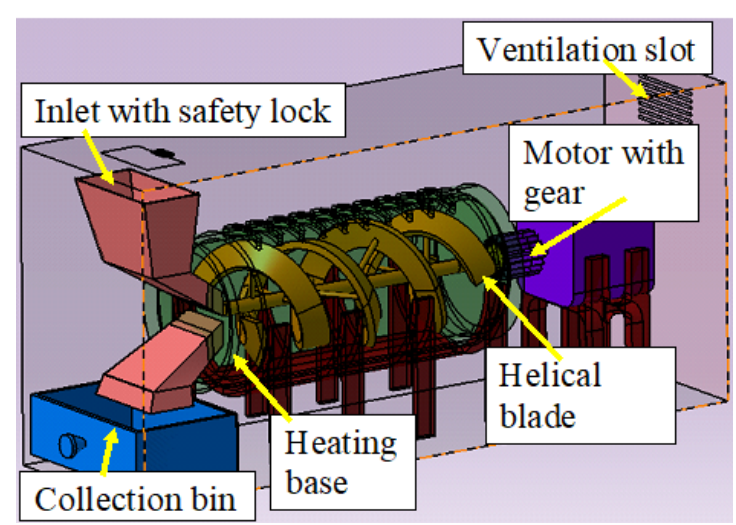

(c)

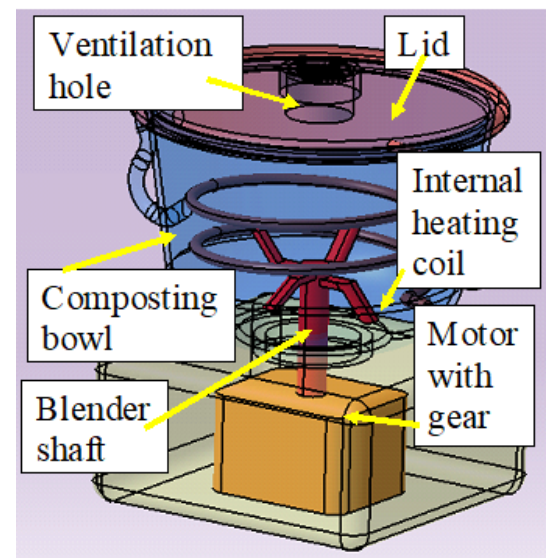

(d)

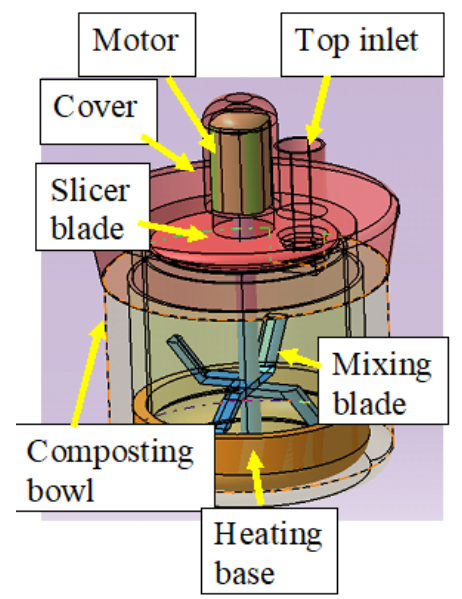

(e)

Fig. 5: a) Design 1, b) Design 2, c) Design 3, d) Design 4 and d) Design 5 of the food waste composter

\subsection{Selection of Design (PUGH Method)}

The evaluation of the proposed conceptual designs is discussed based on the PUGH Method. For this project, the criterion includes the presence of functions such as heating, shredding, mixing, timer, safety lock, ventilation, collection bin, mobility, and temperature control. The datum concept used in this analysis is the current conventional method of composting food waste, i.e., anaerobic composting that has been widely implemented 
until today. The performance of each design with respect to each of the criteria is tabulated in Table 2 and the total score is calculated by multiplying the performance score with the particular important level of the criterion. Symbols '+,' '-' and ' $S$ ' indicate score values of ' 1 ', '-1' and ' 0 ' respectively. For example, the total score of Design 1 is calculated as follows: By using the PUGH Method, Design 1 has recorded the highest score of 27 under evaluation based on the criteria of this project compared to the other four alternative designs; therefore, Design 1 is selected to generate the final concept. On top of that, the scoring table is also tabulated to determine the selection of the composter design, as shown in Table 3. The total weightage of each design criterion is given per $100 \%$ according to its importance. Then, the rating of each design is given within the range of 1 to 5 , where 1 shows the lowest score by each design. Based on the score gained by each design, Design 1 is the final selection based on the total maximum score of 5 .

Table 2. Concept Screening

\begin{tabular}{|c|c|c|c|c|c|c|c|}
\hline Criteria & 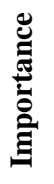 & 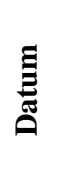 & $\overrightarrow{\overline{0}}$ & 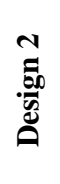 & 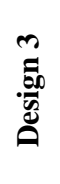 & 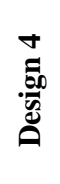 & 足 \\
\hline Heating & 5 & 0 & + & + & + & + & + \\
\hline Shredding & 5 & 0 & + & - & - & - & + \\
\hline Mixing & 5 & 0 & + & + & + & + & + \\
\hline Timer & 3 & 0 & $\mathrm{~S}$ & $\mathrm{~S}$ & $S$ & $\mathrm{~S}$ & $\mathrm{~S}$ \\
\hline Safety Lock & 5 & 0 & $\mathrm{~S}$ & + & + & $\mathrm{S}$ & $\mathrm{S}$ \\
\hline Ventilation & 5 & 0 & + & + & - & + & + \\
\hline Collection bin & 1 & 0 & + & + & - & - & - \\
\hline Mobility & 1 & 0 & + & + & + & + & + \\
\hline Temperature control & 5 & 0 & + & + & + & + & + \\
\hline \multicolumn{3}{|c|}{ Total Score } & 27 & 22 & 10 & 15 & 25 \\
\hline
\end{tabular}

Table 3. Concept Scoring

\begin{tabular}{|c|c|c|c|c|c|c|c|c|c|c|c|}
\hline \multirow{3}{*}{ 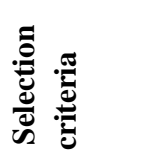 } & \multirow{3}{*}{$\stackrel{\frac{7}{200}}{3}$} & \multicolumn{10}{|c|}{ Food Waste Composter } \\
\hline & & \multicolumn{2}{|c|}{ Design 1} & \multicolumn{2}{|c|}{ Design 2} & \multicolumn{2}{|c|}{ Design 3} & \multicolumn{2}{|c|}{ Design 4} & \multicolumn{2}{|c|}{ Design 5} \\
\hline & & Rating & Score & Rating & Score & Rating & Score & Rating & Score & Rating & Score \\
\hline Heating & 15 & 5 & 0.75 & 5 & 0.75 & 5 & 0.75 & 5 & 0.75 & 5 & 0.75 \\
\hline Shredding & 15 & 5 & 0.75 & 0 & 0 & 0 & 0 & 0 & 0 & 5 & 0.75 \\
\hline Mixing & 15 & 5 & 0.75 & 5 & 0.75 & 5 & 0.75 & 5 & 0.75 & 5 & 0.75 \\
\hline Timer & 5 & 2 & 0.10 & 2 & 0.10 & 2 & 0.10 & 2 & 0.10 & 2 & 0.10 \\
\hline Safety lock & 5 & 2 & 0.10 & 5 & 0.25 & 5 & 0.25 & 2 & 0.10 & 2 & 0.10 \\
\hline Ventilation & 15 & 5 & 0.75 & 5 & 0.75 & 0 & 0 & 5 & 0.75 & 5 & 0.75 \\
\hline $\begin{array}{l}\text { Collection } \\
\text { bin }\end{array}$ & 5 & 5 & 0.25 & 5 & 0.25 & 0 & 0 & 0 & 0 & 0 & 0 \\
\hline Portability & 5 & 5 & 0.25 & 5 & 0.25 & 5 & 0.25 & 5 & 0.25 & 5 & 0.25 \\
\hline $\begin{array}{l}\text { Temperatur } \\
\text { e control }\end{array}$ & 15 & 5 & 0.75 & 5 & 0.75 & 5 & 0.75 & 5 & 0.75 & 5 & 0.75 \\
\hline $\begin{array}{l}\text { Inlet \& } \\
\text { outlet } \\
\text { mechanism }\end{array}$ & 5 & 5 & 0.25 & 5 & 0.25 & 5 & 0.25 & 5 & 0.25 & 5 & 0.25 \\
\hline \multicolumn{2}{|c|}{ Total score ( / 5) } & \multicolumn{2}{|c|}{4.7} & \multicolumn{2}{|c|}{4.1} & \multicolumn{2}{|c|}{3.1} & \multicolumn{2}{|c|}{3.7} & \multicolumn{2}{|c|}{4.45} \\
\hline \multicolumn{2}{|l|}{ Rank } & \multicolumn{2}{|r|}{1} & \multicolumn{2}{|c|}{3} & \multicolumn{2}{|r|}{5} & \multicolumn{2}{|c|}{4} & \multicolumn{2}{|c|}{2} \\
\hline \multicolumn{2}{|c|}{ Continue? } & \multicolumn{2}{|c|}{ Develop } & \multicolumn{2}{|c|}{ No } & \multicolumn{2}{|c|}{ No } & \multicolumn{2}{|c|}{ No } & \multicolumn{2}{|c|}{ No } \\
\hline
\end{tabular}

\subsection{Geometry Modelling}

In this section, the proposed design of this project is drawn using CATIA software, based on Design 1 with the implementation of several improvements to maximise the 
performance of the design in serving its functionality.

An isometric view of the working mechanism, which includes the shredding mechanism, the mixing mechanism, and the heating mechanism, is illustrated Fig. 6. Two shafts which consist of three-hook blades with separators placed alternately in the housing act as the major components that allow shredding of the inserted food waste to be fragmented into smaller pieces for a higher rate of the composting process, as shown in Fig. 7 and 8.

In Fig. 9, the major components of the mixing mechanisms include a helical blade and a bottom blade driven by a detachable motor, which demonstrated the effectiveness of the mixing mechanism to promote even mixing of the food waste pieces. Meanwhile, Fig. 10 shows the heating base attached to the bottom part of the composter.

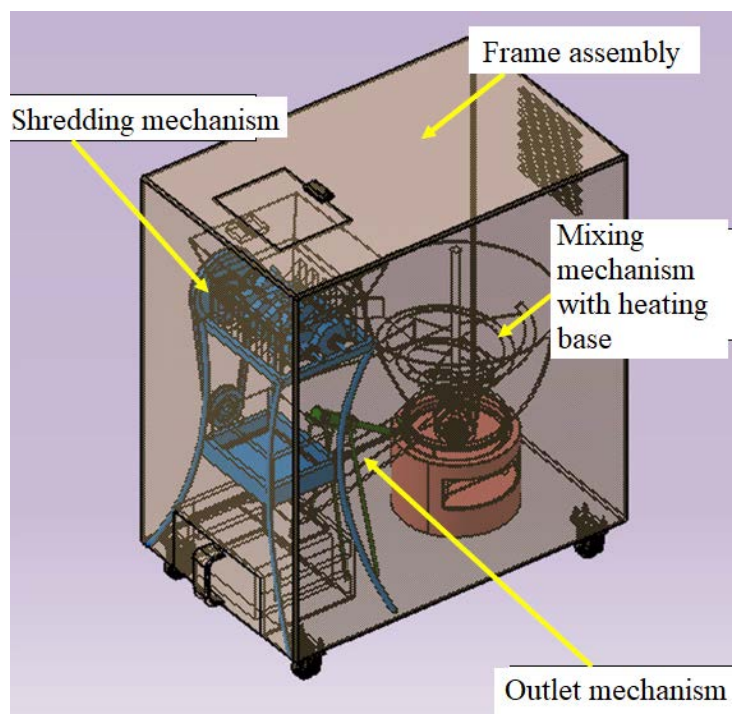

Fig. 6: Isometric view of the major working mechanisms

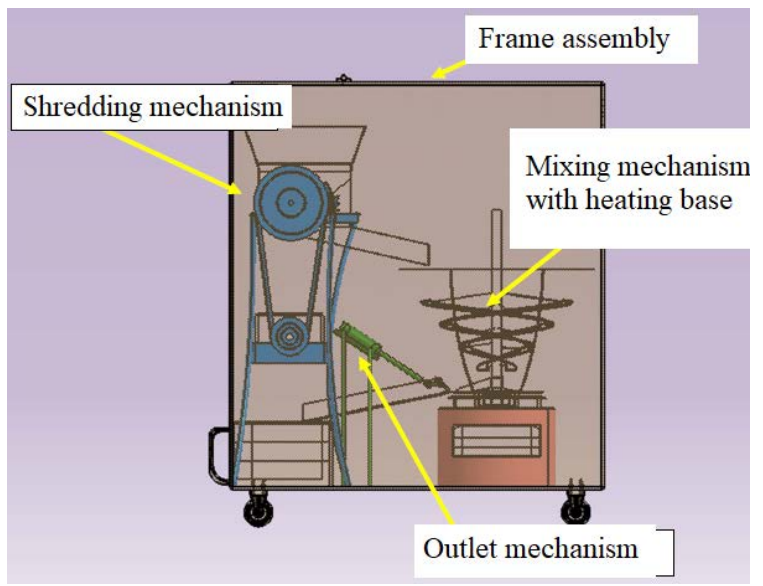

Fig. 7: Shredding mechanism and its components

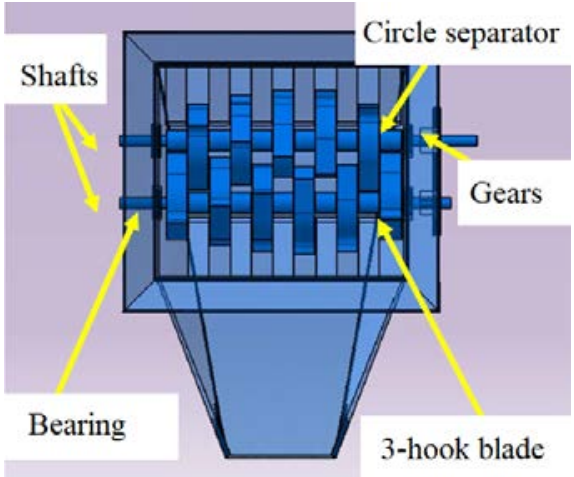

Fig. 8: Arrangement of blades and separators of the shredding mechanism

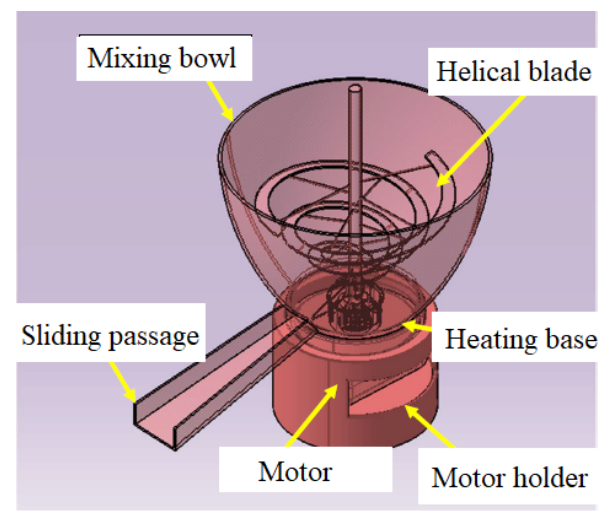

Fig. 9: Mixing mechanism and its components.

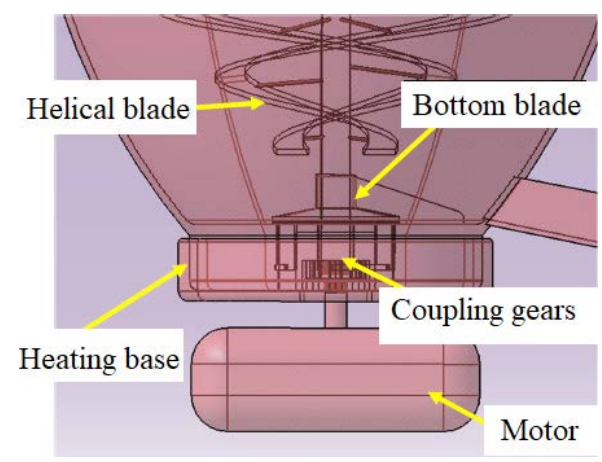

Fig. 10: Heating base complementary to the bowl

\subsection{Flow of Working Mechanism}

The flow of the working mechanism of the designed composter is illustrated in Fig. 11. 


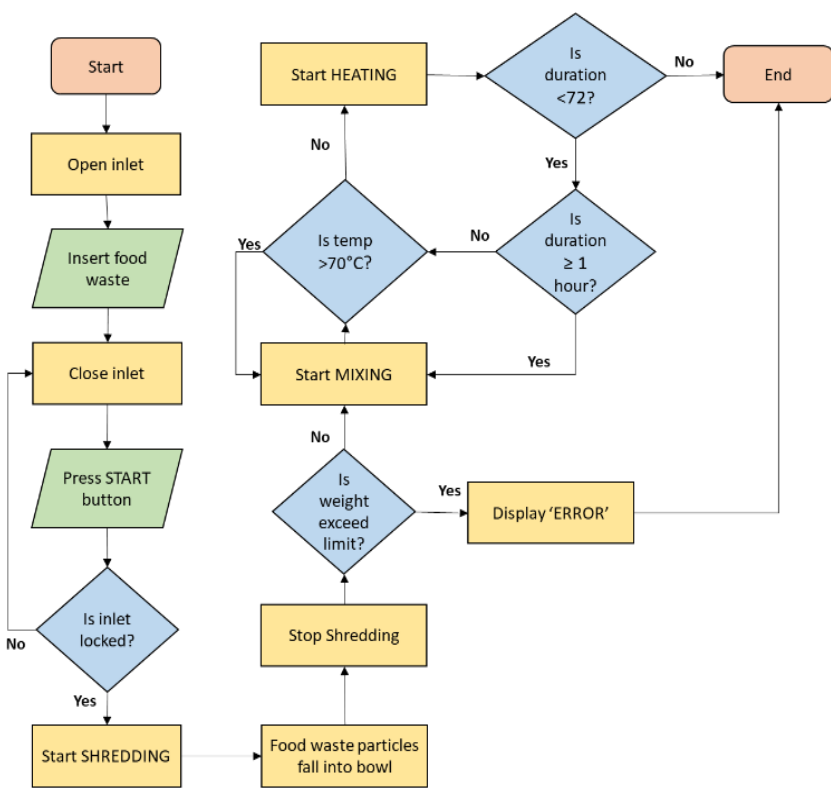

Fig. 11: The flowchart of the composter working mechanism

\subsection{Material Selection}

Three functional mechanisms include mixing, shredding, and heating are crucial in its material selection as these mechanisms define the feasibility of the machine. Therefore, the suggested materials, but not limited to these mechanisms, are illustrated and discussed in Table 4.

Table 4. Material suggestion for crucial components

\begin{tabular}{|c|l|l|l|}
\hline Mechanism & Component & Material & Justification \\
\hline Shredding & Separator & $\begin{array}{l}\text { Stainless } \\
\text { steel }\end{array}$ & $\begin{array}{l}\text {-Corrosion } \\
\text { resistant, high } \\
\text { strength }\end{array}$ \\
\hline Shredding & $\begin{array}{l}\text { 3-hook } \\
\text { blade }\end{array}$ & $\begin{array}{l}\text { Stainless } \\
\text { steel }\end{array}$ & $\begin{array}{l}\text {-Corrosion } \\
\text { resistant, high } \\
\text { strength }\end{array}$ \\
\hline Mixing & $\begin{array}{l}\text { Helical } \\
\text { Blade }\end{array}$ & $\begin{array}{l}\text { Stainless } \\
\text { steel }\end{array}$ & $\begin{array}{l}\text {-Corrosion } \\
\text { resistant, high } \\
\text { strength }\end{array}$ \\
\hline Mixing & Base Blade & $\begin{array}{l}\text { Stainless } \\
\text { steel }\end{array}$ & $\begin{array}{l}\text {-Corrosion } \\
\text { resistant, high } \\
\text { strength }\end{array}$ \\
\hline Mixing & Bowl & $\begin{array}{l}\text {-Corrosion } \\
\text { resistant, high } \\
\text { strength }\end{array}$ \\
\hline Heating & Heating base & $\begin{array}{l}\text { Sickel- } \\
\text { chromium } \\
\text { coating }\end{array}$ & $\begin{array}{l}\text {-Economical, } \\
\text { heat-retaining } \\
\text { ability, } \\
\text { corrosion } \\
\text { resistant }\end{array}$ \\
\hline
\end{tabular}

\subsection{Fabrication Parts}

In this part, the economic view of designing the food waste composter is presented. This details the lowest effective cost, which also applies in designing a roof insulation $^{32}$. An estimation of the fabrication cost of the customised parts without the labour cost is tabulated in Table 5.

Table 5. Fabrication cost

\begin{tabular}{|c|c|c|c|c|}
\hline \multirow{2}{*}{ Mechanism } & \multirow{2}{*}{ Component } & \multirow{2}{*}{ Unit } & \multicolumn{2}{|c|}{ Cost (RM) } \\
\hline & & & Min. & Max \\
\hline \multirow[t]{6}{*}{ Shredding } & Bearing & 4 & 40.00 & 100.00 \\
\hline & $\begin{array}{l}\text { Pulley } \\
\text { driver }\end{array}$ & 1 & 30.00 & 50.00 \\
\hline & $\begin{array}{l}\text { Pulley } \\
\text { driven }\end{array}$ & 1 & 30.00 & 50.00 \\
\hline & 0.3 V-Belt & 1 & 5.00 & 10.00 \\
\hline & Gear & 2 & 300.00 & 500.00 \\
\hline & $\begin{array}{l}2.0 \mathrm{HP} \\
\text { Motor }\end{array}$ & 1 & 200.00 & 300.00 \\
\hline \multirow[t]{3}{*}{ Mixing } & $\begin{array}{l}0.25 \text { HP } \\
\text { Motor }\end{array}$ & 1 & 50.00 & 80.00 \\
\hline & $\begin{array}{l}\text { Mechanical } \\
\text { Timer }\end{array}$ & 1 & 15.00 & 20.00 \\
\hline & Load cell & 1 & 20.00 & 50.00 \\
\hline \multirow[t]{3}{*}{ Outlet } & $\begin{array}{l}\text { Stopper } \\
\text { shaft }\end{array}$ & 1 & 3.00 & 5.00 \\
\hline & Actuator & 1 & 20.00 & 50.00 \\
\hline & Hinge & 1 & 10.00 & 20.00 \\
\hline \multirow[t]{4}{*}{ Frame } & Hinge & 1 & 10.00 & 20.00 \\
\hline & Safety lock & 1 & 8.00 & 20.00 \\
\hline & $\begin{array}{l}\text { Roller } \\
\text { assembly }\end{array}$ & 4 & 20.00 & 80.00 \\
\hline & Switch & 1 & 2.00 & 5.00 \\
\hline \multicolumn{3}{|c|}{ Total } & 763 & 1360 \\
\hline
\end{tabular}

\section{Summary}

The principles of design were implemented in this study to conceptually design the food waste composter. The customer requirements were then linked to the composter design requirement, which was presented using the House of Quality. Then, the detailed product specifications was identified to support the design requirement. The function structure was further used to show the process flow that had occurred within the composter from the major process to the more detailed sub-processes. By using the morphological chart, each item or component involved in the design of the composter was identified and visualised in detail. Hence, five possible composter designs were proposed. The final selection was made using the concept of screening and scoring. Apart from that, the materials of the composter parts were suggested with the cost of the fabrication.

\section{Acknowledgments}

The authors would like to acknowledge the Green and Efficient Energy Technology (GrEET) research group of the Centre for Advanced Research on Energy (CARe), 
Universiti Teknikal Malaysia Melaka (UTeM), and Universitas Pertamina, Jakarta, Indonesia, for encouraging and supporting this research work. The extended abstract of this paper has been accepted in the MERD'20 proceedings.

\section{Nomenclature}

$\begin{array}{ll}\text { MSW } & \text { Municipal Solid Waste } \\ \text { TRIZ } & \text { Theory of Inventive Problem Solving } \\ F & \text { Force }(\mathrm{N}) \\ r & \text { Inner radius of the cylinder }(\mathrm{m}) \\ h & \text { Height of the cylinder. } \\ P & \text { Power }(\mathrm{W}) \\ Q & \text { Heat generated }(\mathrm{J}) \\ m & \text { Mass }(\mathrm{kg}) \\ C & \text { Specific heat capacity or air }(\mathrm{kJ} / \mathrm{kgK}) \\ T & \text { Temperature }\left({ }^{\circ} \mathrm{C}\right) \\ V & \text { Volume }\left(\mathrm{m}^{3}\right) \\ A & \text { Area }\left(\mathrm{m}^{2}\right)\end{array}$

Greek symbols

$\begin{array}{ll}\tau & \text { Torque }(\mathrm{Nm}) \\ r & \text { Radius }(\mathrm{m}) \\ P & \text { Power }(\mathrm{W}) \\ \omega & \text { Radial velocity }(\mathrm{rad} / \mathrm{s}) \\ \sigma & \text { Yield strength }(\mathrm{Pa}) \\ \rho & \text { Density }\left(\mathrm{kg} / \mathrm{m}^{3}\right)\end{array}$

$\begin{array}{cl}\text { Subscripts } & \\ \min & \text { Minimum } \\ s & \text { Shredder blade } \\ 1 & \text { Initial } \\ 2 & \text { final }\end{array}$

\section{References}

1) "Generating more waste than ever," n.d. https://www.thestar.com.my/news/nation/2019/07/30 /generating-more-waste-than-ever (accessed December 4, 2020).

2) A. Gao, Z. Tian, Z. Wang, R. Wennersten, \& Q. Sun, "Comparison between the technologies for food waste treatment.," Energy Procedia, 105 3915-3921. (2017). doi.org/10.1016/j.egypro.2017.03.811.

3) K. Ibadurrohman, I. Gusniani, M. D. Hartono, \& N. Suwartha, "The Potential Analysis of Food Waste Management using Bioconversion of The Organic Waste by The Black Soldier Fly (Hermetia illucens) Larvae in The Cafeteria of The Faculty of Engineering, Universitas Indonesia," Evergreen, 7(1), 61-66 (2020). doi.org/10.5109/2740946.

4) A. Abdul Hamid, A., Ahmad, M. H. Ibrahim, \& N. N.
Nik Abdul Rahman, "Food Waste Management in Malaysia-Current situation and future management options," Journal of Industrial Research \& Technology, 2(1) 36-39 (2012). https://www.semanticscholar.org/paper/Food-WasteManagement-in-Malaysia-Current-situation-HamidAhmad/8becca0d9ed17208e2027d08a92b35e58e3f5 $8 \mathrm{~d} 3$.

5) V. S. Vairagade, \& S. A. Vairagade, "Aerobic Composting of Household Biodegradable WasteAn Experimental Study," In Waste Management and Resource Efficiency, no. Springer, Singapore, 555567

https://link.springer.com/chapter/10.1007/978-98110-7290-1_47.

6) C. Cromell, “Composting for Dummies,” John Wiley \& Sons, Inc., 2010. https://www.wiley.com/enus/Composting+For+Dummies-p-9780470581612.

7) "Zera Food Recycler," n.d. https://wlabsinnovations.com/products/zera-foodrecycler. (accessed December 8, 2020).

8) "Food Cycler," n. d. https://www.foodcycler.com/ (accessed December 8, 2020).

9) J. Welstead, \& J. L. Felder, "Conceptual design of a single-aisle turboelectric commercial transport with fuselage boundary layer ingestion," In 54th AIAA Aerospace Sciences Meeting, 1027 (2016). doi.org/10.2514/6.2016-1027.

10) R. Bhattacharyya, A. Misra, \& K. C. Sandeep, "Photovoltaic solar energy conversion for hydrogen production by alkaline water electrolysis: conceptual design and analysis," Energy Conversion and management, $133 \quad$ (1-13) (2017). doi:10.1016/j.enconman.2016.11.057.

11) T. He, S. K. Nair, P. Babu, P. Linga, \& I. A. Karimi, "A novel conceptual design of hydrate based desalination (HyDesal) process by utilizing LNG cold energy," Applied Energy, 222 13-24 (2018). doi.org/10.1016/j.apenergy.2018.04.006.

12) M. R. Mansor, S. M. Sapuan, E. S. Zainudin, A. A. Nuraini, \& A. Hambali, "Conceptual design of kenaf fiber polymer composite automotive parking brake lever using integrated TRIZ-Morphological ChartAnalytic Hierarchy Process method," Materials \& Design (1980-2015), $54 \quad 473-482 \quad$ (2014). doi: .org/10.1016/j.matdes.2013.08.064.

13) M. F. Ahmad, C. H. Khor, N. Abdul Hamid, N. Sarpin, R. Zainal, A. N. A. Ahmad, \& M. N. Mohd Nawi, "The Impact of Product Design and Process Design towards New Product Performance in Manufacturing Industry: A Survey Result in Malaysia," International Journal of Supply Chain Management (IJSCM), 7(2) 102-106 https://ojs.excelingtech.co.uk/index.php/IJSCM/artic le/view/2173.

14) C. Gao, W. Wang, J. Sun, \& P. Chao, "The application of Function Analysis in development of rehabilitation 
product," in In First International Conference on Information Sciences, Machinery, Materials and Energy. Atlantis Press. (2015). doi: 10.2991/icismme15.2015.64.

15) C. Lu, H. Chai, M. Tian, X. Peng, \& S. Jiang, "Product function combination design based on functional redundancy analysis," Concurrent Engineering, 25(3) 229-244 (2017). doi.org/10.1177/1063293X17705180.

16) S. W. Hsiao and Y. C. Chen, "Concurrent Design in Vacuum Cleaner Development.” International Conference of Organizational Innovation (ICOI 2017): Advances in Intelligent System Research, 131 297-304 (2017). doi: 10.2991/icoi-17.2017.51

17) M. Dragomir, D. Banyai, D. Dragomir, F. Popescu, and A. Criste. "Efficiency and resilience in product design by using morphological charts." Energy Procedia 85 206-210 doi:10.1016/j.egypro.2015.12.218.

(2016).

8) D. Sushil Dange, S. L. Shyam, and K. Prabhu, "Effective Improvement of a Plant Layout Using Pugh Matrix Approach," International Research Journal of Engineering and Technology (IRJET), 5(6) (2018). https://www.irjet.net/archives/V5/i6/IRJETV5I6532.pdf.

19) A. K. Joshi, I. A. Dandekar, M. V. Gaikwad, \& C. G. Harge, "Pugh Matrix and Kano Model-The Significant Techniques for Customer's Survey" International Journal of Emerging Technology and Advanced Engineering, 9(6) (2019). www.ijetae.com (ISSN 2250-2459, ISO 9001:2008 Certified Journal, Volume 9, Issue 6, June 2019).

20) B. T. Prasetyo, M. A. M. Oktaufik, \& S. Himawan, "Design, Construction and Preliminary Test Operation of BPPT-3MW Condensing Turbine Geothermal Power Plant," Evergreen, 6 (2), 162-167 (2019). doi:10.5109/2321012. doi.org/10.5109/2321012.

21) P. Byrne, N. Putra, T. Maré, N. Abdallah, P. Lalanne, I. Alhamid, P. Estelle, A. Yatim, and A. L. Tiffonnet, "Design of a solar AC system including a PCM storage for sustainable resorts in tropical region.," $\begin{array}{lllll}\text { Evergreen, } 6 & \text { (2) } 143-148 \quad \text { (2019). }\end{array}$ doi:10.5109/2321009.

22) Y. Whulanza, A. T. Hakim, S. M. Utomo, R. Irwansyah, \& J. Charmet, "Design and Characterization of Finger-Controlled Micropump for Lab-on-a-Chip Devices," Evergreen, 6 (2) 108113 (2019). doi.org/10.5109/2321002.

23) M. M. Takeyeldein, "Wind Turbine Design Using Thin Airfoil SD2030," Evergreen, 6 (2) 114-123 (2019). doi.org/10.5109/2321003.

24) G. Chiplunkar, \& M. Avinash, "Design of Kitchen Waste Composting Machine: A Smart Approach," International Journal of Trend in Research and Development, $5 \quad$ 41-43 (2018). http://www.ijtrd.com/papers/IJTRD16500.pdf.
25) L. Benjawan, S. Sihawong, W. Chayaprasert, \& W. Liamlaem, "Composting of biodegradable organic waste from Thai household in a semi-continuous composter," Compost Science \& Utilization, 23(1), 11-17 (2015). doi: 10.1080/1065657X.2014.963742.

26) S. J. Kaplan, W. C. Hayes, J. L. Stone, \& G. S. Beaupré, "Tensile strength of bovine trabecular bone," Journal of biomechanics, 18 (9) 723-727 (1985). doi.org/10.1016/0021-9290(85)90027-2.

27) A. Ng, E. Mat Tokit, N. Abd Rahman, N. M. M. Mitan. House of quality method in preliminary design of kitchen food waste composter. Proceedings of Mechanical Engineering Research Day 2020, 279280 https://www3.utem.edu.my/care/proceedings/merd2 0/pdf/08_Mechanical_Design_and_Optimization/12 0-p279_280.pdf.

28) S. Jayaprakash, H. S. Lohit, \& B. S. Abhilash, "Design and development of compost bin for Indian kitchen," Int J Waste Resour, 8(323) 2 (2018). doi:10.4172/2252-5211.1000323.

29) I. O. Christiana, \& A. S. Olusegun, "Design, development and evaluation of a small scale kitchen waste composting machine," IOSR journal of engineering, 4 29-33 (2014). doi: 10.9790/302104462933.

30) H. A. Hamid, L.P. Qi, H. Harun, N. M. Sunar, N. M., F. H. Ahmad, \& M. S. Muhamad, "Development of Organic Fertilizer from Food Waste by Composting in UTHM Campus Pagoh," Journal of Design for Sustainable and Environment, 1(1) (2019). http://eprints.uthm.edu.my/id/eprint/11913.

31) Ng Angie, E. Mat Tokit, F. A. Z. Mohd Sa'at, F. Shikh Anuar, "Conceptual design of kitchen food waste composter using morphological chart.” Proceedings of Mechanical Engineering Research Day 2020, 277278 http://www3.utem.edu.my/care/proceedings/merd20/ pdf/08_Mechanical_Design_and_Optimization/119p277_278.pdf.

32) A. G. Alam, A. Tirta, \& C. K. Priambada, (2019). "Building Beneficial Roof Insulation in Vertical Housing: Physical and Economical Selection Method" $\begin{array}{llll}\text { Evergreen, } 6 & \text { (2), } & \text { 124-133 }\end{array}$ doi.org/10.5109/2321006. 